\title{
Case Report on Less Potent Corticosteroid Induced Altered Mental Status and Its Management At Secondary Care Public Hospital
}

\author{
Chandrasekar Keerthana ${ }^{1}$, Balasubramanian Madhubala ${ }^{1}$, Nanjan Loghraj ${ }^{2}$, Sivasankaran Ponnusankar ${ }^{1 *}$ \\ 'Department of Pharmacy Practice, JSS College of Pharmacy, Udhagamandalam, The Nilgiris. Tamilnadu, INDIA. Jagadguru Sri Shivarathreeshwara University, Mysuru, \\ Karnataka, INDIA. \\ ${ }^{2}$ Govt. District Headquarters Hospital, Udhagamandalam, The Nilgiris. Tamilnadu, INDIA.
}

\begin{abstract}
Objective: Patients receiving high doses of corticosteroids reported developing psychiatric disorders and rarely, Altered Mental Status (AMS) and disorientation is observed. Hence, corticosteroids administration should be discontinued in patients experiencing adverse effects. Methods: The present case report explains the rare adverse effect caused due to corticosteroid administration in a patient with Chronic Obstructive Pulmonary Disease (COPD) and the treatment strategies followed in a secondary care public hospital, Udhagamandalam, India. Case description: She was presented with the complaints of altered sensorium, disorientation, loss of appetite which was caused due to the administration of intravenous hydrocortisone injection. Later the patient experienced confusion, loss of appetite, headache and giddiness which has occurred as a result of drug interaction between Furosemide, Hydrocortisone and Theophylline. Conclusion: Therefore, hydrocortisone administration should be avoided in this patient to prevent the worsening of the present condition, where the patient already is experiencing the adverse effect altered mental status. Monitoring of the signs and symptoms is the key element to prevent the adverse effects.
\end{abstract}

Key words: Altered Mental Status (AMS), Corticosteroid, Chronic Obstructive Pulmonary Disease (COPD) and Elderly Patient.

Key message: Altered Mental Status (AMS) and disorientation is rarely observed as an adverse effect in patients receiving high doses of corticosteroids. Hence, hydrocortisone administration should be avoided in this patient to prevent the worsening of the present condition and monitoring of signs and symptoms is essential to prevent the adverse effects.

\section{Correspondence:}

Dr. Sivasankaran Ponnusankar, Professor \& Head, Department of Pharmacy Practice, JSS College of Pharmacy, Udhagamandalam - 643 001. The Nilgiris. Tamilnadu Jagadguru Sri Shivarathreeshwara University, Mysuru, Karnataka, INDIA.

Phone: +91-9489613428

Email: ponnusankarsivas@gmail.com

DOI: 10.5530/jyp.2018.10.28

\section{INTRODUCTION}

Corticosteroids are widely used pharmacological agents for the treatment of inflammatory diseases like asthma, COPD and auto immune disorders. ${ }^{1}$ Patients receiving high doses of corticosteroids reported developing psychiatric disorders such as depression, mania, psychosis ${ }^{2}$ and the symptoms associated are emotional instability and irritability related to auditory hallucinations. Rarely, Altered Mental Status (AMS) and disorientation is observed. ${ }^{3}$ Symptoms disappear after therapy discontinuation but some patients require therapeutic management. ${ }^{4}$

AMS is a disruption in the brain that causes change in the behavior, for which the pathophysiology is not fully understood, but it may be due to the alteration of the hypothalamic-pituitary-adrenal axis. ${ }^{5}$ The side effects of corticosteroid-induced AMS may happen with any of the following routes of administration like intravenous injection, oral, intraarticular injection, epidural, and topical. The appearance of symptoms can appear at any phase of the therapy (initial phases of the therapy, during or end of therapy). ${ }^{6}$ In $86 \%$ of the cases reported, the adverse effects occurred within first 5 days of treatment. Discontinuation of the corticosteroids is the primary management of neuropsychiatric symptoms occurred due to corticosteroids. Patients who should be managed with corticosteroid due to clinical need, psychiatric opinion should be taken, to determine the need for anti-psychotic or mood-stabilizing medications. Mostly, patients can be managed with Lorazepam 1-2 mg oral or intramuscular. ${ }^{5}$ This present case report explains the rare adverse effect caused due to Hydrocortisone and the treatment strategies followed in a secondary care public hospital.

\section{CASE REPORT}

A 65-year-old woman was presented to the in-patient department of ICU of the secondary care public hospital, Udhagamandalam, The Nilgiris on $2^{\text {nd }}$ July 2016, with complaints of altered sensorium, disorientation, loss of appetite, involuntary bowel and bladder habit for the past four days. Patient was referred from a primary care public hospital, Gudalur. The past medical history of the patient revealed that she is a known case of hypertension and COPD. Patient had a past medication history of injection Hydrocortisone $100 \mathrm{mg}$ IV twice daily, injection Furosemide 60 mg IV stat, injection Ampicillin 1gm twice daily, injection Ranitidine $100 \mathrm{mg}$ IV twice daily, injection Deriphylline $100 \mathrm{mg}$ IV at night, tablet B complex once daily, tablet chlorpheniramine $4 \mathrm{mg}$ twice daily, tablet Paracetamol $500 \mathrm{mg}$ thrice daily, tablet Salbutamol $4 \mathrm{mg}$ twice daily, tablet Amlodipine $20 \mathrm{mg}$.

The vitals of the patient were as follows; Blood Pressure: 130/90 mmHg, Pulse Rate: 84 beats/minutes, Respiratory Rate: 20 breaths/minutes and temperature: 98.4 degree Fahrenheit. The laboratory investigations of the patient was found to be normal (Table 1). Based on the signs and

This is an open access article distributed under the terms of the Creative Commons Attribution-NonCommercial-ShareAlike 4.0 License, which allows others to remix, tweak, and build upon the work non-commercially, as long as the author is credited and the new creations are licensed under the identical terms. 
Table 1: Laboratory Investigation Report

\begin{tabular}{|c|c|c|}
\hline Clinical parameters & Value in patient & Normal range \\
\hline Hemoglobin & $14.3 \mathrm{~g} / \mathrm{dL}$ & $12-16 \mathrm{~g} / \mathrm{dL}$ \\
\hline Total Count & $7.0 \times 10^{3} / \mathrm{mm}^{3}$ & $3.2-9.8 \times 10^{3} \mathrm{cells} / \mathrm{mm}^{3}$ \\
\hline \multicolumn{3}{|l|}{ Differential Count } \\
\hline Polymorphs & $62 \%$ & \\
\hline Lymphocytes & $25 \%$ & $54-62 \%$ \\
\hline Monocytes & $6 \%$ & $25-33 \%$ \\
\hline Platelet count & $190 \times 10^{3} / \mathrm{mm}^{3}$ & $\begin{array}{c}3-7 \% \\
130-400 \times 10^{3} / \mathrm{mm}^{3}\end{array}$ \\
\hline Red Blood Cells & $4.78 \times 10^{6} / \mathrm{mm}^{3}$ & $3.5-5.0 \times 10^{6} / \mathrm{mm}^{3}$ \\
\hline Hematocrit & $42.3 \%$ & $33-43 \%$ \\
\hline Mean cell volume & $88.5 \mathrm{fL}$ & $76-100 \mu \mathbf{m}^{3}$ \\
\hline Mean cell hemoglobin & $29.9 \mathrm{pg} / \mathrm{cell}$ & $27-33 \mathrm{pg} / \mathrm{cell}$ \\
\hline $\begin{array}{l}\text { Mean cell hemoglobin } \\
\text { concentration }\end{array}$ & $33.8 \mathrm{~g} / \mathrm{dL}$ & $33-37 \mathrm{~g} / \mathrm{dL}$ \\
\hline Random blood sugar & $96 \mathrm{mgs} \%$ & $<200 \mathrm{mg} / \mathrm{dL}$ \\
\hline Blood urea & $30 \mathrm{mgs} \%$ & $20-40 \mathrm{mg} / \mathrm{dL}$ \\
\hline Serum creatinine & $0.9 \mathrm{mgs} \%$ & $0.6-1.2 \mathrm{mg} / \mathrm{dL}$ \\
\hline Aspartate aminotransferase & $7.48 \mathrm{U} / \mathrm{L}$ & $0-35 \mathrm{U} / \mathrm{L}$ \\
\hline Alanine aminotransferase & $7.27 \mathrm{U} / \mathrm{L}$ & $0-35 \mathrm{U} / \mathrm{L}$ \\
\hline Alkaline phosphates & $57 \mathrm{U} / \mathrm{L}$ & $30-120 \mathrm{U} / \mathrm{L}$ \\
\hline \multicolumn{3}{|l|}{ Bilirubin } \\
\hline Total & $0.8 \mathrm{mgs} \%$ & $0.1-1 \mathrm{mg} / \mathrm{dL}$ \\
\hline Direct & $0.2 \mathrm{mgs} \%$ & $0-0.2 \mathrm{mg} / \mathrm{dL}$ \\
\hline Indirect & $0.4 \mathrm{mgs} \%$ & $0.1-0.8 \mathrm{mg} / \mathrm{dL}$ \\
\hline \multicolumn{3}{|l|}{ Urine Analysis } \\
\hline Urine sugar & Nil & Nil \\
\hline Urine albumin & Nil & Nil \\
\hline Pus cells & $1-2 / \mathrm{hpf}$ & $1-2 / \mathrm{hpf}$ \\
\hline Epithelial pus cells & $1-2 / \mathrm{hpf}$ & $1-2 / \mathrm{hpf}$ \\
\hline
\end{tabular}

Total Count (TC); Differential Count (DC); Platelet count (Pt); Red Blood Cells (RBC's); Mean cell volume (MCV); Mean cell hemoglobin (MCH); Mean cell hemoglobin concentration (MCHC); Random blood sugar (RBS); Serum creatinine (Sr.cr); Aspartate aminotransferase (SGOT); Alanine aminotransferase (SGPT); Alkaline phosphates (ALP); Pus cells (pc); Epithelial pus cells (epc)

symptoms, patient was diagnosed as altered sensorium due to Hydrocortisone.

On day 1, she was administered with Intravenous Fluid Ringer Lactate 1 pint $100 \mathrm{ml} /$ hour, Normal Saline 1 pint $100 \mathrm{ml} /$ hour, injection Ranitidine $100 \mathrm{mg}$ IV twice daily, injection B12 $2000 \mathrm{mcg} / \mathrm{ml}$ IM once daily. On day 2 injection Cefotaxime $1 \mathrm{gm}$ IV twice daily was added to her prescription. On day 3 she had a complaint of left shoulder pain, confusion and she was treated with analgesic such as tablet Paracetamol $500 \mathrm{mg}$ twice daily, and vitamin supplement such as tablet B complex once daily, was added to her prescription. On day 4 she had a complaint of headache, giddiness and continued the same treatment. On day 5 the patient was referred to Coimbatore Medical College and Hospital $(\mathrm{CMCH})$ for neurologist opinion but the patient was not willing to get transferred, so she was managed with the limited facilities available in the secondary care government hospital. On day 6 the patient had no specific complaint and was discharged at request with the following medications tablet Atorvastatin $20 \mathrm{mg}$ once daily, tablet Ranitidine 150mg twice daily, tablet multivitamin once daily, tablet Ciprofloxacin $500 \mathrm{mg}$ once daily for 5 days.

\section{DISCUSSION}

Commonly in respiratory diseases, systemic corticosteroids are used for the treatment of acute exacerbations of COPD ${ }^{1}$. Recent studies reported that reversible and dose-dependent memory impairment occurs with high-dose Hydrocortisone $(160 \mathrm{mg} /$ day= $40 \mathrm{mg} /$ day prednisolone equivalents) but not with low-dose Hydrocortisone $(40 \mathrm{mg} /$ day= $10 \mathrm{mg} /$ day prednisolone equivalents) administration. ${ }^{7}$ There is not much evidence whether gender affects the ability to develop psychiatric signs and symptoms, but few studies suggest that women with asthma and COPD are more prone to develop disorientation and disorganized speech. ${ }^{5,7}$ Few case studies showed that altered mental status developed with the administration of $200 \mathrm{mg}$ per day of intravenous Hydrocortisone injection. ${ }^{8}$

Neuropsychiatric side-effects occur in up to $18 \%$ of patients on corticosteroids, in that $75 \%$ report showed that psychiatric symptoms are reversible upon the discontinuation of corticosteroids. ${ }^{5,6}$ Psychiatric side effects due to corticosteroids appear to be dose dependent; they occur in $1.3 \%$ of the cases when the dose is $40 \mathrm{mg}$ daily and $18.4 \%$ for doses of $80 \mathrm{mg}$ daily. ${ }^{5}$

In this patient, Hydrocortisone was prescribed which the least potent corticosteroid is, but on high dose $(200 \mathrm{mg})$ it caused altered mental status. ${ }^{1}$ According to Nottingham University Hospital guidelines for the management of neuropsychiatric side effects of corticosteroids suggests that the patient should be managed by discontinuation of the corticosteroid therapy. ${ }^{5}$ The patient was advised for neurologist opinion in tertiary care public hospital, Coimbatore. Due to her low socio economic status, she was not willing to transfer to the hospital and hence she was treated with the limited facility available in the secondary care public hospital, Udhagamandalam which may be considered as a barrier for the treatment outcome in this patient. ${ }^{5}$

In this patient, increased blood pressure and COPD was managed with Furosemide $60 \mathrm{mg}$, Hydrocortisone $100 \mathrm{mg}$, Theophylline $100 \mathrm{mg}$ and Amlodipine $20 \mathrm{mg}$. In that Furosemide and Hydrocortisone causes moderate interaction that result in muscle pains or cramps, loss of appetite, weakness, dizziness, and confusion. On day 3, the patient was observed to be confused and had a complaint of loss of appetite. This may be due to the drug interaction between furosemide and hydrocortisone. ${ }^{9}$ Therefore, in this patient, the co- administration of these drugs should be avoided for the good prognosis.

Similarly, Theophylline and Hydrocortisone co- administration causes hypokalemia and increased theophylline levels which may result in weakness, giddiness, headache, confusion, tingling of the extremities, or feelings of heaviness in the legs. On day 4 , the patient had complaints of giddiness and headache, which may be caused as a result of increased theophylline levels. ${ }^{9}$ Therefore, monitoring of potassium level and other electrolyte levels is recommended for this patient. Corticosteroids reduce the therapeutic effect of the antihypertensive and diuretics. ${ }^{10}$ Therefore, monitoring of blood pressure once in a week should be recommended for this patient.

\section{CONCLUSION}

Patient was managed with limited facility available in secondary care public hospital, Udhagamandalam. In this patient corticosteroid therapy should be stopped and an alternative therapy, long acting Beta2 agonist (Formoterol inhaler $4.5-9 \mathrm{mcg}$ twice daily) is recommended for the management and acute exacerbations of COPD. ${ }^{11}$ Early dietary modification such as low calorie, low sodium, and high potassium should be 
considered in this patient ${ }^{10}$. Patient family should be counselled about the adverse effects of hydrocortisone and should tell them the importance of mental support to be provided to the patient. Monitoring of the adverse effects and drug interactions is very important to prevent the worsening of the symptoms.

\section{ACKNOWLEDGEMENT}

The authors acknowledge the support provided by the doctors and administration of the Government District Headquarters Hospital, Udhagamandalam.

\section{CONFLICT OF INTEREST}

There are no conflict of interest.

\section{ABBREVIATION USED}

COPD: Chronic Obstructive Pulmonary Disease; AMS: Altered Mental Status; ICU: intensive care unit; IV: Intra Venous; IM: Intra Muscular.

\section{REFERENCE}

1. Liu D, Ahmet A, Ward L, Krishnamoorthy P, Mandelcorn ED, Leigh R, et al. A practical guide to the monitoring and management of the complications of systemic corticosteroid therapy. Allergy Asthma Clin Immunol. 2013;9(1):30.
2. Corticosteroid- related central nervous system side effects. The Boston Collaborative Drug Surveillance Program. Clinical Pharmacol Ther. 1972;13:694-8.

3. Benyamin RM, Vallejo R, Kramer J, Rafeyan R. Corticosteroid induced psychosis in the pain management setting. Pain Physician. 2008;11(6):917-20.

4. Kahn D, Stevenson E, Douglas CJ. Effect of sodium valproate in three patients with organic brain syndromes. Am J Psychiatry. 1988;145(8):1010-1.

5. Basu S, Schofield C. Guideline on management of neuropsychiatric side-effects of steroids. Nottingham University Hospital. 2013:1-5.

6. Ciriaco M, Ventrice P, Russo G, Scicchitano M, Mazzitello G, Scicchitano F, et al. Corticosteroid- related central nervous system side effects. J Pharmacol Pharmacother. 2013;4(Suppl1):S94-S8

7. Brown ES, Chandler PA. Mood and cognitive changes during systemic corticosteroid therapy. Prim Care Companion J Clin Psychiatry. 2001;3(1):17-21.

8. Raghavendra BN, Govind SB, Nanasaheb MP, Sameeran SC. Psychosis in patients with systemic lupus erythematosus. Indian J Psychol Med. 2012;34(1):90-3.

9. Medscape [internet]. Available from: https://www.drugs.com/interactions check.php?drug_list=1146-0,2379-0 [Accessed 19th may 2017].

10. Stanbury R, Graham E. Systemic corticosteroid therapy- side effects and their management. Br J Ophthalmol. 1998;82(6):704-8

11. Global Initiative for Chronic Obstructive Lung Disease, Pocket guide to COPD diagnosis, management and prevention, A guide for health care professionals 2017.

Article History: Submission Date : 28-09-2017 ; Revised Date : 23-10-2017; Acceptance Date : 25-11-2017.

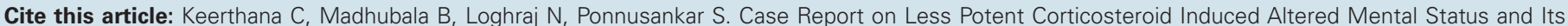
Management At Secondary Care Public Hospital. J Young Pharm. 2018;10(1):126-8. 